\title{
Peridotite xenoliths of the Chidliak kimberlite province (NE Canada): The North Atlantic cratonic mantle with recent thermal and Ti-Na metasomatic disturbance
}

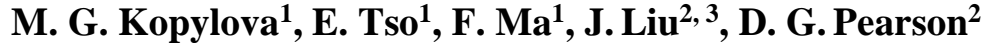 \\ 1 - University of British Columbia, Vancouver, Canada; mkopylov@eos.ubc.ca, etso@eoas.ubc.ca; \\ FrankMa92@hotmail.com \\ 2 -University of Alberta,Edmonton, Canada; jingao@cugb.edu.cn, gdpearso@ualberta.ca \\ 3 - China University of Geosciences, Beijing, China
}

We studied the petrography, mineralogy, thermobarometry and whole rock chemistry of 120 peridotite and pyroxenite xenoliths collected from the 156-138 Ma Chidliak kimberlite province (Southern Baffin Island). Xenoliths from pipes $\mathrm{CH}-1,-6,-7$, and -44 are divided into two garnetbearing series, peridotites and wehrlites - olivine pyroxenites. The peridotites may contain spinel (37$62 \mathrm{wt} \% \mathrm{Cr}_{2} \mathrm{O}_{3}$ ), while wehrlites may contain picroilmenite. Peridotites and wehrlites show widely varying textures, from coarse to sheared. Xenoliths from the CH-6 pipe differ from xenoliths in other pipes in terms of their petrography and relative abundances of rock types. Textures indicating the late formation of garnet and clinopyroxene are present in all xenolith series, with the most common texture being garnet mantled by clinopyroxene. Pyroxenes are invariably rimmed by secondary calcic minerals, which appear as dark coronas. SEM observations identify these as 3-15 micron thick mantles of clinopyroxene (on orthopyroxene) and monticellite (on clinopyroxene).

Olivine is more magnesian in coarse peridotites with spinel $(\mathrm{Mg \# =91-93)}$ than in garnet-bearing coarse and sheared peridotites $(\mathrm{Mg \# =89-94)}$ or wehrlites $(\mathrm{Mg} \#=85-92)$. Enstatites in $\mathrm{CH}-6$ peridotites are on average lower in $\mathrm{CaO}, \mathrm{Cr}_{2} \mathrm{O}_{3}, \mathrm{Al}_{2} \mathrm{O}_{3}, \mathrm{TiO}_{2}$, and $\mathrm{Na}_{2} \mathrm{O}$ than those in peridotites from $\mathrm{CH}-1,-7$, and -44. Cr-diopsides in all rock types from $\mathrm{CH}-6$ are less titaniferous than $\mathrm{Cr}$-diopsides from other pipes. Garnets are predominantly chromian pyropes from the lherzolitic $\mathrm{CaO}-\mathrm{Cr}_{2} \mathrm{O}_{3}$ field.

Chidliak xenoliths yield equilibration temperatures between 600 and $1300^{\circ} \mathrm{C}$ and pressures between 20 and $74 \mathrm{~kb}$ (Fig. 1). The CH-6 pipe samples shallow to deep mantle spanning the entire P-T range, while pipes $\mathrm{CH}-1,-7,-44$ exclusively sample deeper mantle at $\mathrm{P}>50 \mathrm{~kb}$. The pressure-temperature array in shallow $(\mathrm{P}<50 \mathrm{~kb})$ Chidliak mantle falls on conductive geotherms with $33-35 \mathrm{~mW} / \mathrm{m}^{2}$ surface heat flow. There is a sharp change of the thermal state at $\mathrm{P} \sim 50 \mathrm{~kb}$, where a cold, shallow mantle is underlain by a hotter, thermally heterogeneous, disturbed mantle with temperatures between 1000 and $1300^{\circ} \mathrm{C}$. In the mantle beneath the $\mathrm{CH}-6$ pipe, coarse peridotites occupy shallower depths than sheared peridotites. The deepest samples $(\mathrm{P}>64 \mathrm{~kb})$ are represented by coarse wehrlites and sheared peridotites. The mantle sampled by $\mathrm{CH}-1,-7$, and -44 pipes also demonstrates a change from marginally shallower coarse peridotites to deeper (54-65 kb) sheared peridotites. Wehrlites from $\mathrm{CH}-$ $1,-7$, and -44 pipes are derived from the shallow mantle where they were not accompanied by any coexisting rock types, but also occur deeper, together with coarse and sheared peridotites. The thermal state of Chidliak's shallow mantle $(\mathrm{P}<50 \mathrm{~kb})$ resembles that of the Slave and Siberian cratons, and is distinctly colder than the Kaapvaal mantle, but hotter than the shallow mantle in Fennoscandia. The cool shallow geotherm and very high proportion of thermally disturbed deeper samples suggest that the Chidliak mantle is analogous to the Udachnaya cratonic mantle section.

The whole rock major element chemistry of the Chidliak xenoliths reflects initial high levels of melt depletion typical of cratonic mantle, and subsequent refertilization in $\mathrm{Ca}$ and Al. Chidliak samples have higher $\mathrm{CaO}$ contents relative to $\mathrm{Al}_{2} \mathrm{O}_{3}$ compared to other cratonic peridotites. Almost half of the Chidliak samples fall off the global $\mathrm{Mg} / \mathrm{Si}-\mathrm{Al}$ trend due to excess $\mathrm{Al}$ for a given $\mathrm{Mg} / \mathrm{Si}$ ratio; this pattern matches the observed late development of Al-rich minerals such as garnet and clinopyroxene. The peridotites and wehrlites, on average, have $83 \pm 9$ vol.\% Ol, $7 \pm 7$ vol.\% Opx, $4 \pm 4$ vol.\% Cpx, and $6 \pm 4$ vol.\% Gar as determined by computer-assisted modal analysis of 120 scanned thin section images. The Chidliak mantle plots close to the "shallow oceanic melt extraction" trend (Fig. 2), being rich in 
forsteritic olivine; these compositional traits resemble the North Atlantic Craton (NAC) rather than the more orthopyroxene-rich mantle of other cratons. We assign the more complex Ca-Al systematics of the Chidliak peridotites to repeated episodes of Ca-rich, Si-poor metasomatism, which introduced clinopyroxene and garnet, and later replaced orthopyroxene and clinopyroxene with secondary clinopyroxene and monticellite. The calcic metasomatism was most likely carbonatitic by nature and is manifest in its greatest extent by the formation of wehrlites and "diffuse" veins of pyroxenites. The carbonatitic metasomatism was accompanied by an influx of $\mathrm{Fe}$, which lowered the olivine $\mathrm{Mg}$ numbers in wehrlites (Fig. 2). The metasomatism acted upon the entire sampled mantle depth, from 35 to $70 \mathrm{~kb}$, where clinopyroxene and garnet modes are uniformly and heterogeneously high in the $\sim 110 \mathrm{~km}$ deep mantle segment. Equally wide-ranging are Mg-numbers of olivine, defining spans of 4 units at each given pressure.

The Chidliak lithospheric mantle is Archean in age (Liu et al., 2017). It demonstrates strong compositional similarity with only one adjacent block of the cratonic mantle, the North Atlantic Craton (NAC). It is distinctly different from the mantle samples studied so far from the equally proximal Rae and Superior cratons. The Chidliak mantle resembles the NAC in its bulk composition (e.g., Wittig et al., 2008), by the dominance of carbonatitic rather than silicic metasomatism, as well as by its mineral chemistry and the Sr-Nd characteristics of the mantle reservoirs for kimberlites (Heaman et al., 2015). We interpret these features as representing the former contiguous nature of the mantle beneath Chidliak and the NAC extant on W. Greenland, prior to the subsequent rifting into separate continental fragments. The carbonatitic metasomatism and introduction of calcic minerals affected cratonic blocks on a regional scale including the proximal blocks of the NAC and the Chidliak mantle. The identical Sr-Nd systematics of the West Greenland Proterozoic kimberlites and Jurassic Chidliak kimberlites suggests that this unique geochemical reservoir must have developed during Neoproterozoic mantle metasomatic activity. The area may have been in a single Archean NAC that incorporated the Chidliak block, or may have developed in the northeastern part of Laurentia after its $1.8 \mathrm{Ga}$ amalgamation.

Another, more recent type of mantle metasomatism, which affected the Chidliak mantle, is characterised by $\mathrm{Ti}-\mathrm{Na}$ enrichment. It is expressed as elevated $\mathrm{Ti}$ in clinopyroxene and elevated $\mathrm{Na}$ and $\mathrm{Ti}$ in garnet, typical of Chidliak sheared peridotites from $\mathrm{CH}-1,-7$, and -44 . The $\mathrm{CH}-6$ xenolith suite largely excludes such samples. The metasomatized deep mantle shows 1) a high ratio of sheared to coarse samples; 2) a high proportion of mosaic-porphyroclastic samples among sheared peridotites; and 3) temperatures varying isobarically by up to $200^{\circ} \mathrm{C}$, indicative of a higher convective heat flow. As represented by the xenolith suite, the Ti-Na metasomatic imprint extends across depths from 55 to $65 \mathrm{kbar}$. The horizontal scale of the imprint is more ambiguous and could be as regionally extensive as 10 's of kms, or as local as $<1 \mathrm{~km}$. The latter scale is constrained by the varied abundance of Tienriched garnets within a single kimberlite, which may reflect differential depth sampling of a metasomatically stratified mantle, or different intensities of Ti-Na metasomatism at the scale of individual kimberlites. We postulate that the Ti-Na (megacryst-like) style of metasomatism is genetically related to textural modification and/or thermal transients that affected the deep Chidliak mantle. The time-scale of such transient events relates to a conductive length-scale and could be between 10's Kyr and 1-2 Myr. A highly localized influx of hot hydrous proto-kimberlite fluids rich in $\mathrm{Ti}, \mathrm{Na}$ and other magmaphile elements weakened the mantle, and triggered formation of sheared peridotites.

\section{References:}

Heaman LA, Pell J, Grütter HS, Creaser RA (2015) U-Pb geochronology and Sr/Nd isotope compositions of groundmass perovskite from the newly discovered Jurassic Chidliak kimberlite fields, Baffin Island, Canada. Earth Planet Sci Letters 415: 183-199

Liu J, Pearson DG, Harris GA, Kopylova MG, Tso E (2017). Age and evolution of the lithospheric mantle beneath southern Baffin Island, Nunavut, Canada. $11^{\text {th }}$ IKC Extended Abstract 11IKC-4584

Nimis P, Grütter H (2010) Internally consistent geothermometers for garnet peridotites and pyroxenites. Contrib Miner Petrol 159 (3): 411-427 
Wittig N, Pearson DG, Webb M, Ottley CJ, Irvine GJ, Kopylova M, Jensen SM, Nowell GM (2008)

Origin of cratonic lithospheric mantle roots: A geochemical study of peridotites from the North Atlantic Craton, West Greenland. Earth Planet Sci Letters 274 (1-2): 24-33

(a)

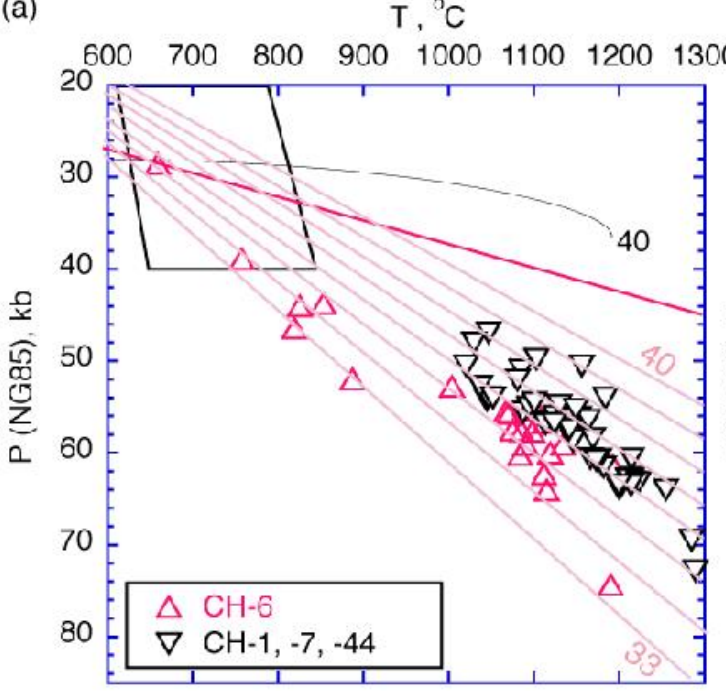

(b)

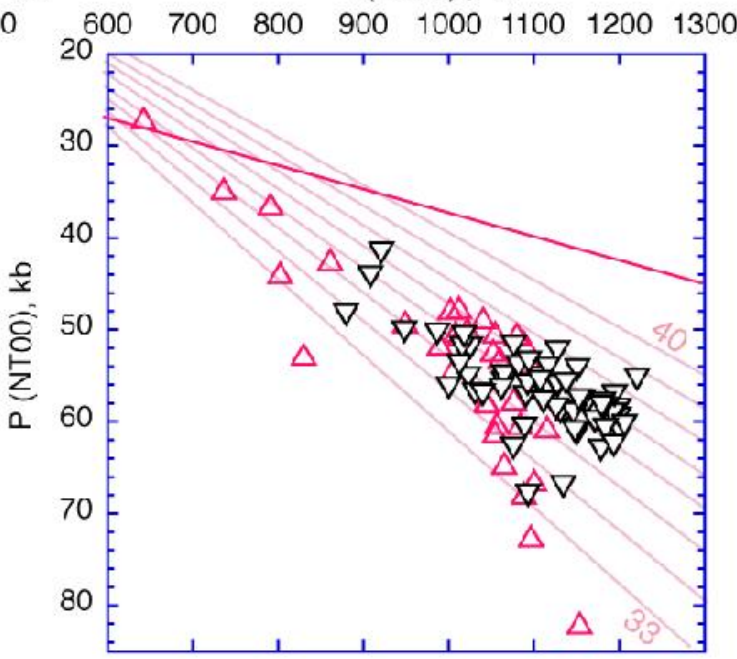

Fig. 1. Pressure-temperature plots for Chidliak peridotites. (a): Taylor (1998) thermometer for lherzolites and the Nimis \& Grütter (2010) thermometer for harzburgites combined with the Nickel \& Green (1985) barometer; (b): Nimis \& Taylor (2000) thermobarometry, only samples that passed all tests for inter-mineral equilibrium are plotted. The open rhombic field on panel (a) corresponds to a possible range of temperatures for spinelbearing lherzolites at assumed pressures from 20 to $40 \mathrm{~kb}$. Black curve marked " 40 " in (a) shows the pressure of equilibration of a single spinel-garnet harzburgite (O'Neill, 1981) with $\mathrm{Cr}_{2} \mathrm{O}_{3}$ in spinel $=40 \mathrm{wt} . \%$ and $\mathrm{XFe}^{3+}=-$ 0-0.1 for peridotite containing olivine Fo92. All references for thermobarometers are in Nimis \& Grütter (2010). Model conductive geotherms labeled $33-40 \mathrm{~mW} / \mathrm{m}^{2}$ are from Hasterok \& Chapman (2011). The red line is the graphite-diamond transition curve (Day, 2012).
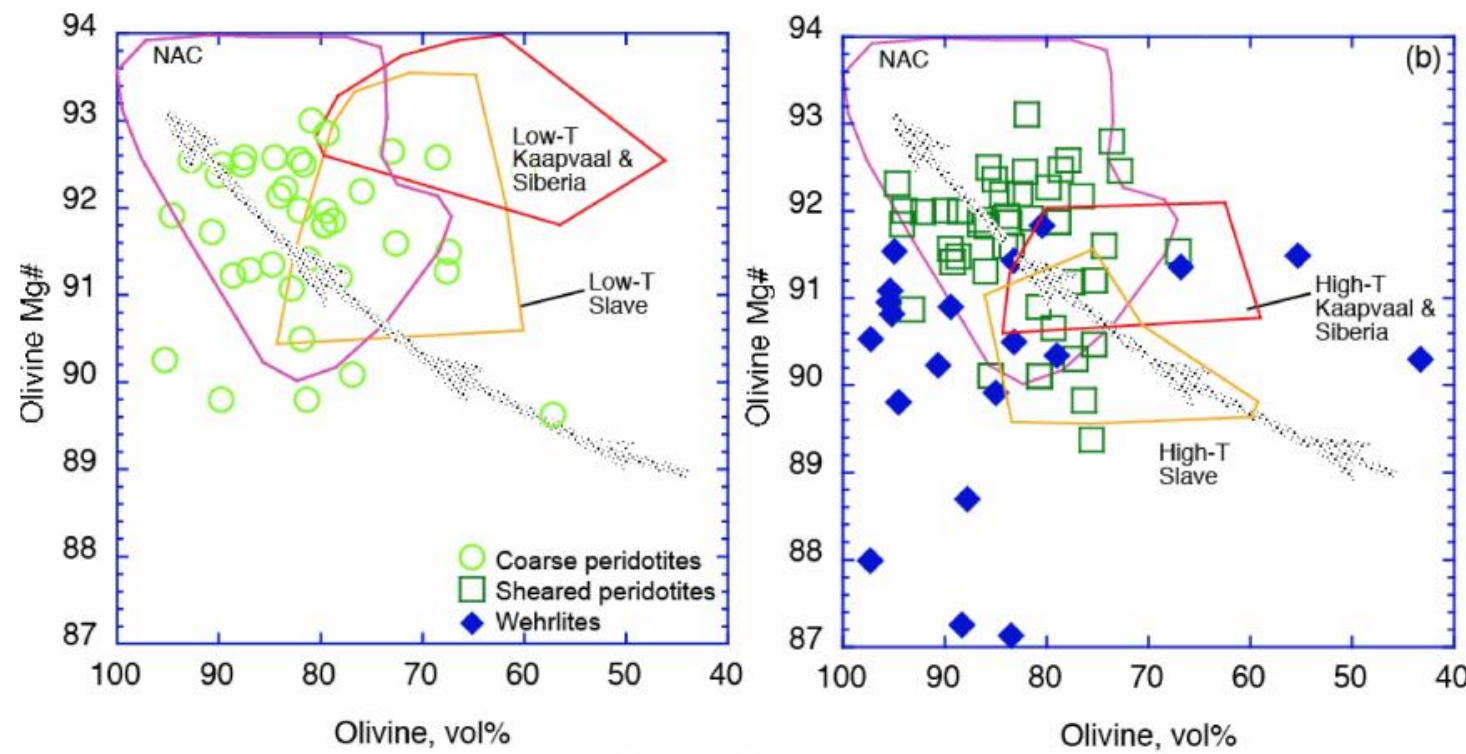

Fig. 2. Olivine mode vs. olivine $\mathrm{Mg}$-number $(\mathrm{Mg} /(\mathrm{Mg}+\mathrm{Fe}), \mathrm{mol} . \%)$ for Chidliak xenoliths in comparison with the Kaapvaal, Slave and North Atlantic Cratons (NAC). (a): Coarse Chidliak peridotites with fields for low-T Kaapvaal \& Siberia (red field) and Slave (yellow field) (Kopylova and Russell, 2000). The latter field includes spinel and garnet peridotites. (b): Sheared Chidliak peridotites and wehrlites with fields for high-T Kaapvaal \& Siberia (red outline) and Slave (yellow outline) (Kopylova and Russell, 2000). The North Atlantic Craton data are from Pearson and Wittig (2008). Grey patterned arrows are the "shallow oceanic trend" of Boyd (1989). 